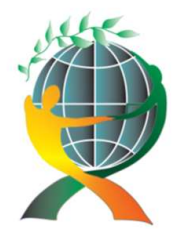

\author{
(online) $=$ ISSN $2285-3642$ \\ ISSN-L = $2285-3642$ \\ Journal of Economic Development, Environment and People \\ Volume 8, Issue 3, 2019 \\ URL: http://jedep.spiruharet.ro \\ e-mail: office jedep@spiruharet.ro
}

\title{
Analysis of the Main Employment Trends at EU and Romanian Levels
}

\author{
Daniela Pașnicu ${ }^{1}$, Cătălin Ghinararu ${ }^{2}$ \\ ${ }^{1}$ Spiru Haret University, National Scientific Research Institute for Labor and Social Protection \\ ${ }^{2}$ National Scientific Research Institute for Labor and Social Protection
}

\begin{abstract}
Lately, the European Union has made progress in the labor market, especially in terms of employment, except in the economic crisis. The purpose of the article is to highlight the main labor market trends at European Union level, with an emphasis on employment as well as differences between Member States in the context of current challenges, namely long-term demographic trends and technological change. In this respect, two EU Member States, namely Romania and the UK, were also taken into account in order to highlight the differences between advanced and less advanced economies in terms of employment opportunities and the integration of vulnerable people on the labor market. The analysis, which emphasizes demographic change and employment, can serve as a basis for knowledge for the design of national policy instruments by emphasizing deficits, surpluses or equilibria. Trends are analysed dynamically over the 20072017 period, based on EUROSTAT data. The challenge for decision-makers is to increase labor force participation and to ensure that every citizen has the chance to make full use of his productive potential.
\end{abstract}

Keywords: labor market, demography, employment, NEET's, gender gap

JEL Codes: J01, J11, J18, J21

How to cite: PASNICU, D., \& GHINARARU, C. (2019). Analysis of the Main Employment Trends at EU and Romanian Levels. Journal of Economic Development, Environment and People, 8(3), 22-31. doi: http://dx.doi.org/10.26458/jedep.v8i3.638.

\section{Introduction}

After the economic crisis in 2008, the evolution of the employment rate registered an ascending trend starting with 2013, both at the EU28 level and in the two analysed cases, Romania and the UK. If the employment rate continues to rise at the pace since 2013, the employment rate targets set by the Europe 2020 Strategy could be reached, both at EU28 and in Romania, respectively by an increase of 2, 8p.p. at the EU28 level and 1.3\% in Romania. EU accession and the economic crisis have facilitated important changes in labor market dynamics in the new Central and Eastern European member states (Trif et al., 2016) and generated labor shortages in some countries and sectors as a result of occupational mobility (Kaminska and Kahancova, 2011). 


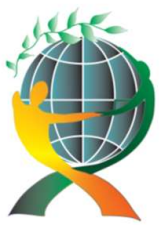

\author{
(online) = ISSN $2285-3642$ \\ ISSN-L = $2285-3642$ \\ Journal of Economic Development, Environment and People \\ Volume 8, Issue 3, 2019 \\ URL: http://jedep.spiruharet.ro \\ e-mail: office jedep@spiruharet.ro
}

The growth of jobs in the services sector continued, but this has been further mitigated lately and there have been signs of recovery in the construction and manufacturing sector (Cedefop, 2016). As well as new opportunities and challenges related to technological developments, automation, artificial intelligence and new forms of work, combined with globalization and the aging of the population emerge in the labour market. The size of the discouraging effects of looking for a job for young people, long-term unemployed, older people, women, people with low education, young people who are not professionally trained and do not have any education or training (NEETs) indicates that there are still structural weaknesses in the economy.

The number of older people is rising rapidly due to the increase in longevity and demographic dependence is expected to double by 2060 at EU level28 (European Commission, 2018). At the same time, the active population will continue to decline in the coming decades, which will likely limit the potential growth of the European Union. The challenge for policy-makers will be to give every citizen the opportunity to make full use of his productive potential, maximize this potential and share it fairly between generations (European Commission, 2017).

The first sections of the article illustrate the complexity of current and prospective labor market issues as well as the breakdown of the objectives and indicators underlying the analysis undertaken to highlight the main trends in the labor market. Despite significant advances in the Romanian labor market after the economic recession, it is still observed that there is a major gap between it and the labor markets of the advanced economies of the European Union, especially with regard to the total employment rate and for the groups disadvantaged, remuneration of employees on the background of lower labor productivity and employment opportunities. In order to avoid national imbalances, it is necessary to regularly anticipate demographic trends, including the phenomenon of migration, employment trends and the need for qualifications.

\title{
2. Objectives and indicators
}

In this article, we have proposed an analysis of the main labor market trends at the level of the European Union as well as differences between Member States in the context of current challenges, namely long-term demographic trends and technological change. In this respect, two EU Member States, namely Romania and the UK, were also taken into account in order to highlight the differences between advanced and less advanced economies in terms of employment opportunities and the integration of vulnerable people on the labor market. Depending on the availability of data, the EU27 (without Croatia), the EU27 (without the United Kingdom), the EU15 and the euro area EA18 și EA19 (refers at European Union countries that have adopted the euro as the single currency) have been envisaged to analyse the dynamics of indicators at European level in order to highlight trends with irreversible character, in conditions of maximum integration of countries. Interpretation of these indicators may be restricted in some cases due to similarity of values, such as EU27, EU28 and EA19, EA18 cases. In the analysis of the employment trends, the emphasis was on demographic change in order to identify its main challenges for the labor market. Romania has been introduced into the analysis to identify certain deficiencies, pluses or convergence compared to the EU28 or UK situation that can be an important knowledge base for designing policy tools at national level. The United Kingdom (UK) choice was made on the basis of a comparative analysis of the situation on the Romanian labor market with an economically advanced Member State. 


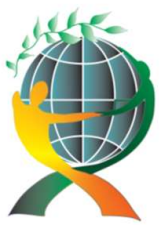

\author{
(online) = ISSN $2285-3642$ \\ ISSN-L = $2285-3642$ \\ Journal of Economic Development, Environment and People \\ Volume 8, Issue 3, 2019 \\ URL: http://jedep.spiruharet.ro \\ e-mail: office jedep@spiruharet.ro
}

The analysis of the main employment trends will be made in dynamic, on socio-economic dimensions, between 2007 and 2017, using Eurostat data, based on the following indicators: structure of population on age; employment rate on age, gender, education; share of newly employed persons; young people in NEETs (not in Education, Employment, or Training). It also analyses the graphical correlations between the employment rate and the vacancy rate and the employment rate and productivity. Interpretation of these indicators may be limited in some cases due to similarity of values, such as EU27, EU28 and EA19, EA18 cases (previously defined).

\title{
3. Results and discussions
}

\subsection{Demographic issues at UE28 level}

Although the population of the EU-28 as a whole increased in 2018, estimated at 1 January 2018 to 512.7 million people, the population of 9 Member States declined compared with 2017 (Bulgaria, Greece, Croatia, Italy, Latvia, Lithuania, Hungary, Portugal, Romania). In 2018, the number of inhabitants in the EU28 increased by more than 100 million people as compared to 1960, but the growth rate has gradually slowed over the last decades. The relative size of the EU's working-age population is declining due to the aging of the population. The EU28 faces a growing population but aging, driven by low fertility rates and a steady increase in life expectancy. This trend, which is already evident in many Member States, will lead to a higher proportion of older people and a lower proportion of the population aged between 20 and 64 in the total population in the coming decades (European Commission, 2015).

Between 2002 and 2017, the number of people aged 65 and over increased by $26.9 \%$ at EU 28 level. The increase was particularly strong for the 80 -year-old group, with more (58.1\%), while for the active population aged 20-64 the growth was slow, with only $2.7 \%$ during the same period. The number of children aged 0 to 19 decreased by $5.7 \%$. The latest population projections support the continuation of these trends, an increase in the number of elderly people accompanied by a decrease in the $20-64$ age group: from $59.7 \%$ in 2017 , to $56.0 \%$ in 2030 and $53.2 \%$ in 2040 . This means a decrease of more than 12 million people by 2030 and more than 24 million by 2040 in this age group. At the same time, the number of elderly people aged 65 or over will increase by 25.8 million by 2030 , which means that in 2030 almost every fourth person in the EU28 will be 65 or over.

Graph 1: Age structure by population, by age group, EU28, 2002, 2017, 2020, 2030 and 2040 (\%)

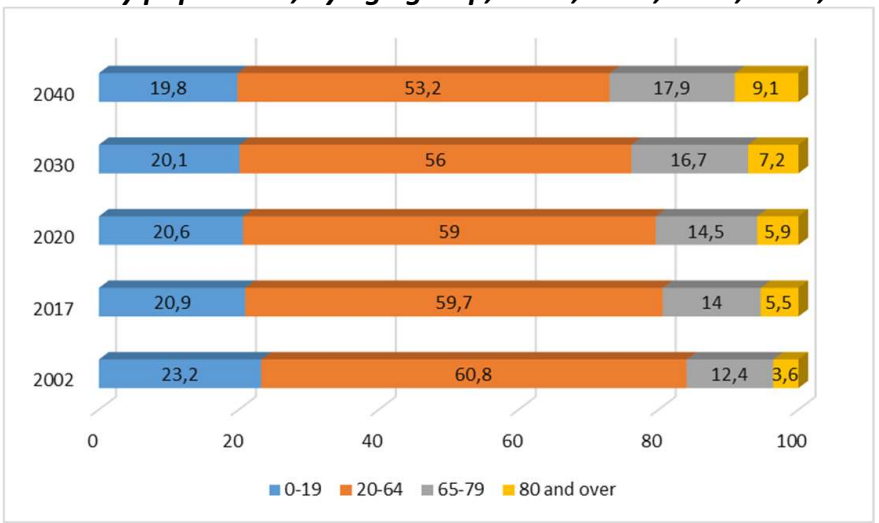

Data source: EUROSTAT 


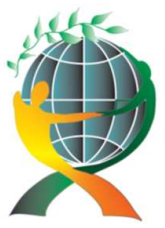

\author{
(online) $=$ ISSN $2285-3642$ \\ ISSN-L = $2285-3642$ \\ Journal of Economic Development, Environment and People \\ Volume 8, Issue 3, 2019
}

URL: http://jedep.spiruharet.ro

e-mail: office jedep@spiruharet.ro

\title{
3.2. Trends in employment
}

\section{$>$ Total employment rate}

In 2008-2017, the employment rate increased across the EU28 as a result of the growth in most Member States, with strongest growth in Malta (12.2 pp) and Hungary (11.8 pp). However, in 10 Member States (Greece, Cyprus, Spain, Denmark, Finland, Croatia, the Netherlands, Latvia, Italy and Ireland), employment rates were still below the 2008 level. In dynamic terms, the effects of the economic crisis felt on the labor market in 2009-2013, after which there is an increase in all analysed cases. Moreover, in 2017, nine Member States - Ireland, the Czech Republic, Lithuania, Estonia, Germany, Sweden, Latvia, Malta and Croatia - have already reached their national employment targets.

The total employment rate for the $20-64$ age range reached $72.2 \%$ in the EU28, $71 \%$ in the euro area (AE19), 68.8\% in Romania (RO) and 78, 2\% in the UK (MB). In 2017, employment rates in the Member States ranged from $57.8 \%$ in Greece to $81.8 \%$ in Sweden. The countries of Central and Northern Europe recorded the highest rates. Among the top five countries with the highest employment rates are Sweden, Germany (79.2\%), Estonia (78.7\%), the Czech Republic (78.5\%) and the United Kingdom (78.2\%) and Greece, Italy $(62.3 \%)$, Croatia (63.6\%), Spain (65.5\%) and Belgium $(68.5 \%)$ are among the countries with the lowest employment rates. Romania ranks 6 th in the rising hierarchy of Member States according to the employment rate, positioning itself after Belgium.

Table 1. Total employment rate for EU Member States, age group 20-64 (\%)

\begin{tabular}{|c|c|c|c|c|c|c|c|c|c|c|c|c|c|c|}
\hline geo\time & 2007 & 2008 & 2009 & 2010 & 2011 & 2012 & 2013 & 2014 & 2015 & 2016 & 2017 & TARG & \begin{tabular}{|l|} 
growth \\
$2017 / 2$ \\
007
\end{tabular} & \begin{tabular}{|l|} 
growth \\
$2017 / 20$ \\
08 \\
\end{tabular} \\
\hline EU28 & 69,8 & 70,3 & 69 & 68,6 & 68,6 & 68,4 & 68,4 & 69,2 & 70,1 & 71,1 & 72,2 & 75 & 2,4 & 19 \\
\hline EU27 & 9,9 & 70,3 & 69 & 68,6 & 68,6 & 68,5 & 68,5 & 69,3 & 70,1 & 71,2 & 72,3 & 75 & 2,4 & \\
\hline Euro area 19 & 69,9 & 70,2 & 68,8 & 68,4 & 68,4 & 68 & 67,7 & 68,2 & 69 & 70 & 71 & & 1,1 & 0,8 \\
\hline Euro area 18 & 69,9 & 70,2 & 68,8 & 68,4 & 68,4 & 68 & 67,7 & 68,2 & 68,9 & 69,9 & 70,9 & & 1 & 0,7 \\
\hline Belgium & 67,7 & 68 & 67,1 & 67,6 & 67,3 & 67,2 & 67,2 & 67,3 & 67,2 & 67,7 & 68,5 & 73,2 & 0,8 & 0 \\
\hline Bulgaria & 68,4 & 70,7 & 68,8 & 64,7 & 62,9 & 63 & 63,5 & 65,1 & 67,1 & 67,7 & 71,3 & 76 & 2,9 & 0,6 \\
\hline Czect & 72 & 72,4 & 70,9 & 70,4 & 70,9 & 71,5 & 72,5 & 73,5 & 74,8 & 76,7 & 8,5 & 75 & 6,5 & 6,1 \\
\hline Den & 79 & 79,7 & 77,5 & 75,8 & 75,7 & 75,4 & 75,6 & 75,9 & 76,5 & 77,4 & 6,9 & 80 & $-2,1$ & -2 , \\
\hline Germany & 72,9 & 74 & 74,2 & 75 & 76,5 & 76,9 & 77,3 & 77,7 & 78 & 78,6 & 99,2 & 77 & 6,3 & 5, \\
\hline Estonia & 76,9 & 77,1 & 70 & 66,8 & 70,6 & 72,2 & 73,3 & 74,3 & 76,5 & 76,6 & 78,7 & 76 & 1,8 & 1 , \\
\hline Ireland & 75,1 & 73,5 & 68 & 65,5 & 64,6 & 64,5 & 66,5 & 68,1 & 69,9 & 71,4 & 73 & 69 & $-2,1$ & $-0,5$ \\
\hline Gre & 65,8 & 66,3 & 65,6 & 63,8 & 59,6 & 55 & 52,9 & 53,3 & 54,9 & 56,2 & 57,8 & 70 & -8 & $-8,5$ \\
\hline Spain & 69,7 & 68,5 & 64 & 62,8 & 62 & 59,6 & 58,6 & 59,9 & 62 & 63,9 & 65,5 & 74 & $-4,2$ & \\
\hline Fran & & & & & & & & 69,2 & 69,5 & 70 & 0,6 & 75 & \#\#\#\#\#\# & \#\#\#\#\#\# \\
\hline Croati & 63,9 & 64,9 & 64,2 & 62,1 & 59,8 & 58,1 & 57,2 & 59,2 & 60,6 & 61,4 & 53,6 & 62,9 & $-0,3$ & $-1,3$ \\
\hline Italy & 62,7 & 62,9 & 61,6 & 61 & 61 & 60,9 & 59,7 & 59,9 & 60,5 & 61,6 & 62,3 & 67 & $-0,4$ & $-0,6$ \\
\hline Cypre & 76,8 & 76,5 & 75,3 & 75 & 73,4 & 70,2 & 67,2 & 67,6 & 67,9 & 68,7 & 70,8 & 75 & -6 & $-5,7$ \\
\hline Latvia & 75,2 & 75,4 & 66,6 & 64,3 & 66,3 & 68,1 & 69,7 & 70,7 & 72,5 & 3,2 & 74,8 & 73 & $-0,4$ & $-0,6$ \\
\hline Lith & 72,7 & 72 & 67 & 64,3 & 66,9 & 68,5 & 69,9 & 71,8 & 73,3 & 75,2 & 76 & 72,8 & 3,3 & \\
\hline Luxe & 69,6 & 68,8 & 70,4 & 70,7 & 70,1 & 71,4 & 71,1 & 72,1 & 70,9 & 70,7 & 71,5 & 73 & 1,9 & 2,7 \\
\hline Hun & 62,3 & 61,5 & 60,1 & 59,9 & 60,4 & 61,6 & 63 & 66,7 & 68,9 & 71,5 & 3,3 & 75 & 11 & 11,8 \\
\hline Malta & 58,6 & 59,2 & 59 & 60,1 & 61,6 & 63,1 & 64,8 & 66,4 & 67,8 & 69,6 & 71,2 & 70 & 12,6 & 12 \\
\hline Netherlands & 77,8 & 78,9 & 78,8 & 76,8 & 76,4 & 76,6 & 75,9 & 75,4 & 76,4 & 77,1 & 78 & 80 & 0,2 & $-0,9$ \\
\hline Austria & 72,8 & 73,8 & 73,4 & 73,9 & 74,2 & 74,4 & 74,6 & 74,2 & 74,3 & 74,8 & 75,4 & 77 & 2,6 & 1,6 \\
\hline Poland & 62,7 & 65 & 64,9 & 64,3 & 64,5 & 64,7 & 64,9 & 66,5 & 67,8 & 69,3 & 70,9 & 71 & 8,2 & 5,9 \\
\hline Por & 72,5 & 73,1 & & 70,3 & 68,8 & 66,3 & 65,4 & 67,6 & 69,1 & 70,6 & 3,4 & 75 & 0,9 & 0,3 \\
\hline Romania & 64,4 & 64,4 & 63,5 & 64,8 & 63,8 & 64,8 & 64,7 & 65,7 & 66 & 66,3 & 58,8 & 70 & 4,4 & 4,4 \\
\hline Slove & 72,4 & 73 & 71,9 & 70,3 & 68,4 & 68,3 & 67,2 & 67,7 & 69,1 & 70,1 & 73,4 & 75 & 1 & 0,4 \\
\hline Slovakia & 67,2 & 68,8 & 66,4 & 64,6 & 65 & 65,1 & 65 & 65,9 & 67,7 & 69,8 & 1,1 & 72 & 3,9 & 2,3 \\
\hline \begin{tabular}{|l} 
Finland \\
\end{tabular} & 74,8 & 75,8 & 73,5 & 73 & 73,8 & 74 & 73,3 & 73,1 & 72,9 & 73,4 & 74,2 & 78 & $-0,6$ & $-1,6$ \\
\hline Sweden & 80,1 & 80,4 & 78,3 & 78,1 & 79,4 & 79,4 & 79,8 & 80 & 80,5 & 81,2 & 81,8 & 80 & 1,7 & 1,4 \\
\hline United Kingdom & 75,2 & 75,2 & 73,9 & 73,5 & 73,5 & 74,1 & 74,8 & 76,2 & 76,8 & 77,5 & 78,2 & & 3 & \\
\hline
\end{tabular}

Data source: EUROSTAT

In 2017, the EU27 labor market continued to show signs of improvement, boosted by economic growth, global prospects and macroeconomic policies. The growth rate of employment in 2017 compared to 2016 is: 


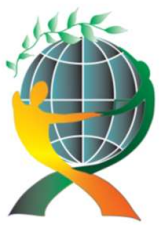

\author{
(online) = ISSN $2285-3642$ \\ ISSN-L = $2285-3642$ \\ Journal of Economic Development, Environment and People \\ Volume 8, Issue 3, 2019 \\ URL: http://jedep.spiruharet.ro \\ e-mail: office jedep@spiruharet.ro
}

$1.1 \%$ of EU28; $1 \% \mathrm{AE} 19 ; 0.7 \% \mathrm{MB}$ and $2.5 \% \mathrm{RO}$. It should be noted that the employment rate of EU28 citizens was $76.1 \%$ in 2017 , with 15.8p.p. higher than non-EU28 citizens.

$>$ Employment rate by age group

The employment rate records the smallest values for the age range of 55-65 years in all analyzed cases. Lower employment rates then of the 20-64 range were registrated between $55-65$ years $(57.1 \%$ EU28, 57.2\% EU27, 57.2\% AE19 and 57.1\% AE18, 64.1\% MB; 44.5\% RO) and $20-29$ years (63.9\% EU28 and EU27, 60.9\% $A E 19$ and $A E 18,76.5 \% \mathrm{MB}$ and $59.4 \% \mathrm{RO}$ ). Significantly higher values are in the range $25-54$ years, ie: $79.6 \%$ EU28; 78.1\% ZE19; 83.8\% MB; 79.9\% RO. The trend of age employment curves respects that recorded for the 20-64 age range. Eichhorst and others (2014) argue that there is no competition between young and older workers on the labor market and it must be developed active polices for both groups.

The main reasons why young people face difficulties in moving from education to work are: segmentation of the labor market and variability in the performance of education and training systems, availability of quality work experience, and the effectiveness of tailored support provided to young people by public employment services of the labor force. Concerned is the fact that in the 2007-2017 period, young people registered a decrease in the employment rate in EU28, respectively: (-1.6\%) EU28; (-4.9\%) AE19. For Britain and Romania, increases of $1.8 \% \mathrm{MB}$ and $4.7 \% \mathrm{RO}$ are recorded.

Graph 2. Total employment rate for age group 20-29 (\%)

Graph 3. Total employment rate for age group 50-65 (\%)

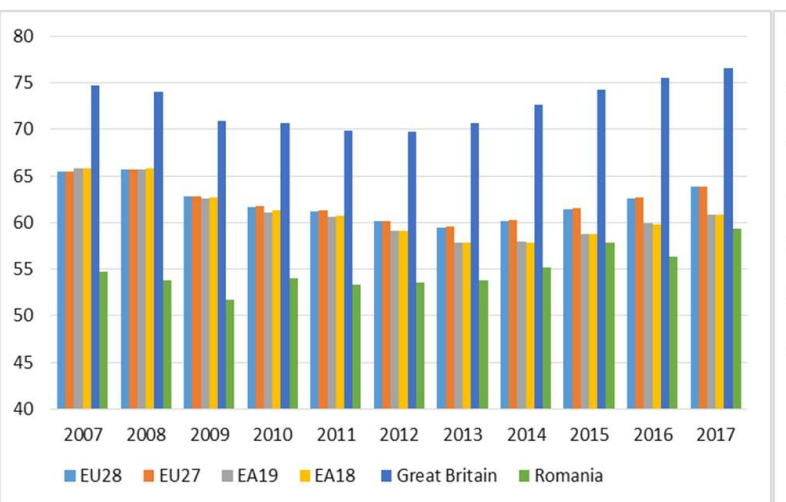

Source: Author's processing by EUROSTAT data

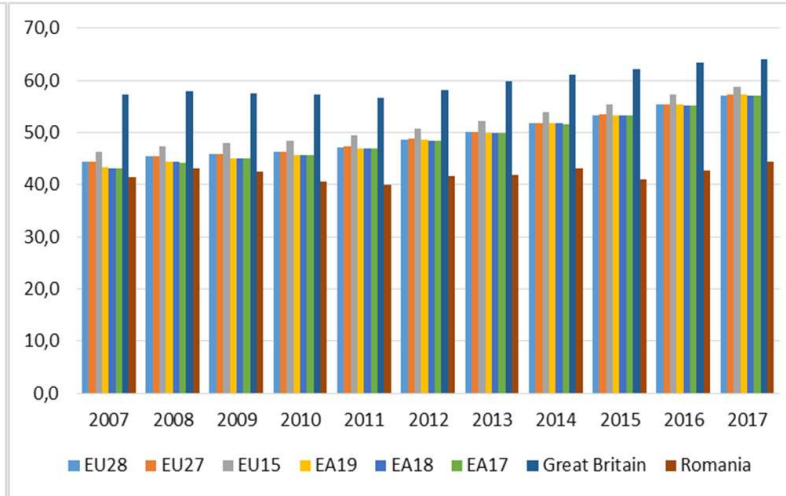

Source: Author's processing by EUROSTAT data

The higher value of the employment rate in Romania, over the EU average, recorded for the age range 25-54 and the values below the EU27 average recorded for the other age groups analyzed, indicates certain imbalances and the need to step up active measures to support employment for people in the affected age groups, especially in the 55-65 age group, where Romania recorded the largest gap in 2017, compared to the EU28 (12.6\%). It is encouraging that for the age group 55-65 years there are increases in the time interval considered in all the analyzed cases, the lowest growth being recorded for Romania, namely: $12.6 \%$ (EU28); $13.9 \%$ (AE19); $6.7 \%$ (MB) and 3.1\% (RO). Increasing the employment rate among older workers is one of the main drivers of total employment growth in the EU28. These increases may be linked to structural factors such as cohorts with better educational outcomes, especially for women, changes in the age pyramid (population age structure) showing the magnitude of the demographic aging phenomenon of the population, and recent pension reforms, such as increasing retirement age, early retirement age, and duration of 


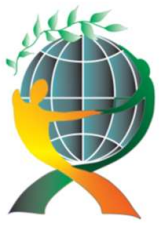

\author{
(online) = ISSN $2285-3642$ \\ ISSN-L = $2285-3642$ \\ Journal of Economic Development, Environment and People \\ Volume 8, Issue 3, 2019 \\ URL: http://jedep.spiruharet.ro \\ e-mail: office jedep@spiruharet.ro
}

contribution to the pension system. These aspects have influenced the prolongation of active life for both women and men.

\title{
$>$ Gender gap on employment
}

The gender gap in employment for the 20-64 age group has a declining trend for 2007-2017 in most of the analysed cases (EU28, EU27, AE19, AE18, UK), with the exception of Romania showing an upward trend until 2016 , where it reaches the maximum value (17.6 pp), and will decrease slightly in 2017. Romania recorded higher values than those in the EU28 starting with 2009, reaching 20\% in 2017: 11.5pp. UE28; 11,2 p.p. AE19 p .; 10,3p.p. MB 17,1p.p. EN. The high value of the gender gap in Romania can be explained by the low employment rate of women, which, although rising in 2017, is well below EU28 (66.5\% EU28 and $60.2 \% \mathrm{RO})$. A number of structural factors that influence women's participation in the labor market could explain how the gender gap in employment in the EU27 has fallen by raising the female employment rate. These include changes in social values and attitudes; Policies that enable women to reconcile work with domestic responsibilities, such as the provision of childcare services, flexible working hours; reducing financial barriers; improved mechanisms to encourage parental engagement and pension reforms. European employment policies that promote new forms of flexibility and security address the specific situation of women to help increase the employment rate.

The gender gap for the 55-64 age group is higher than the age group 20-64. In the analysed range it is decreasing in most of the analysed cases except in Romania, where it is increasing since 2011. In 2017, the indicator reaches the following values: 12,8pp. EU28 and 27; AE19 11.9; MB 10.2 p.p. and RO 20.4 pp. The employment rate of Romanian women in this age group is well below the level of the other analysed cases, the values being as follows: 34.9 RO; 50.9 UE28; 53.1 EU15; 51.4 AE19, 59.1 MB). This can be explained by early retirement, non-participation in the labor market when younger or reflecting the lack of care facilities for grandchildren, dependent parents or other carers.

Graph 4. Gender gap on employment, age group 20-29 (\%) Graph 5. Gender gap on employment, age group 55-64 (\%)

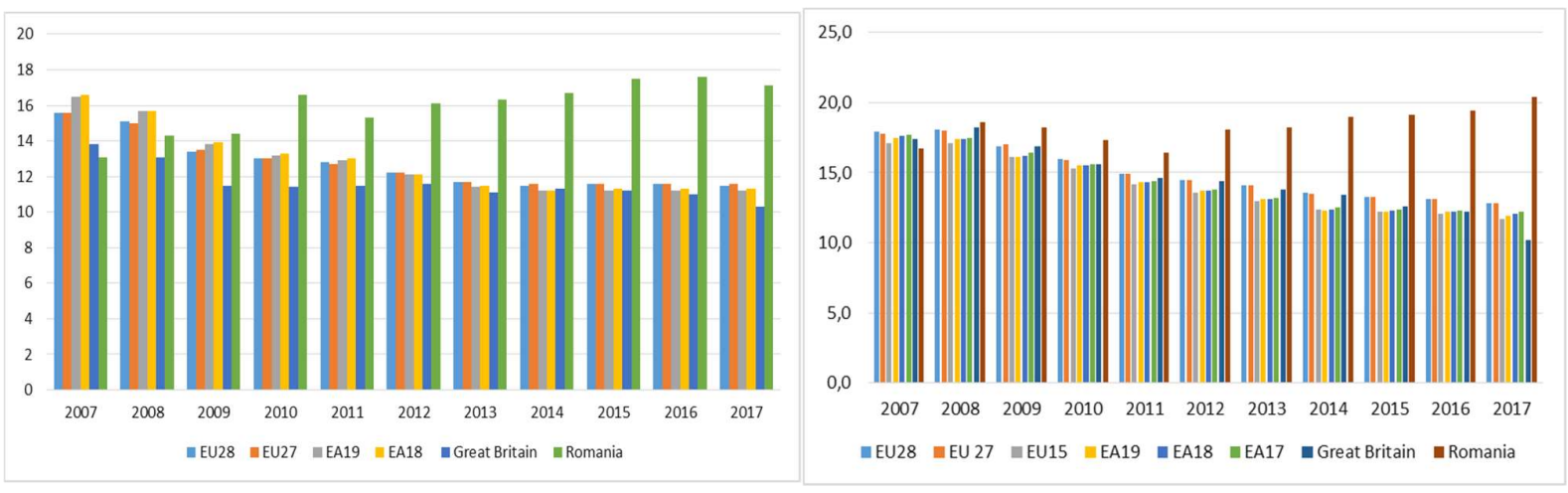

Source: Author's processing by EUROSTAT data

Source: Author's processing by EUROSTAT data

\section{Employment rate by level of education}

The level of education is a major factor influencing employment rates. Employment rates are higher for better educated people, reaching the following values in 2017: 84\% (EU28); 83.1\% (AE19); 85.1\% (MB) 


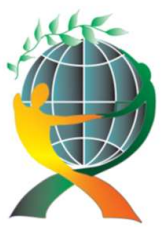

\author{
(online) = ISSN $2285-3642$ \\ ISSN-L = $2285-3642$ \\ Journal of Economic Development, Environment and People \\ Volume 8, Issue 3, 2019 \\ URL: http://jedep.spiruharet.ro \\ e-mail: office jedep@spiruharet.ro
}

and $87.9 \%$ (RO). In 2017, the employment rate among tertiary education graduates was much higher than the total average with 11.8 pp. in EU28 and 19.1 p.p. in Romanian. Only a little over half of those who have reached primary or secondary education have been employed - 54.9\% (EU28); 54.4\% (AE19); 63.6\% (MB) and $54.7 \%$ (RO). The employment rate for people with medium education was between the two mentioned levels. The rise of the proportion of highly educated people is very important for increase overall participation rate on the labor market (Gros, 2019) and reducing in-work poverty (Ghenta, 2017). Raising the level of education and endowing people with skills for the knowledge-based society is a major concern of European employment policies that address the core objectives of the Europe 2020 strategy on employment and education.

\title{
3.3. Creating jobs
}

Employment rates are closely linked to the economic cycle. This is usually expressed in terms of GDP growth, which can be seen as a measure of the dynamism of an economy and its ability to create jobs. The link between GDP growth and employment growth is also reflected in the share of new entrants, expressed by the share of current job holders of 12 months or less in total employment. In 2017, the share of newly employed people, which is an indicator of job creation, accounted for $15.2 \%$ in the EU28; EU27, EA19, EA18; $17.8 \%$ in the UK and only 6.6 in Romania. It declined considerably in 2009 as a result of the economic downturn and the fall in GDP and employment. Labor market challenges can be transformed into opportunities through multidimensional and innovative approaches (OECD 2011, OECD 2012). Also, measures for the development of SMEs in terms of effects on employment have an important role to play (Pasnicu, 2018).

Graph 6: Newly employed persons (\%)

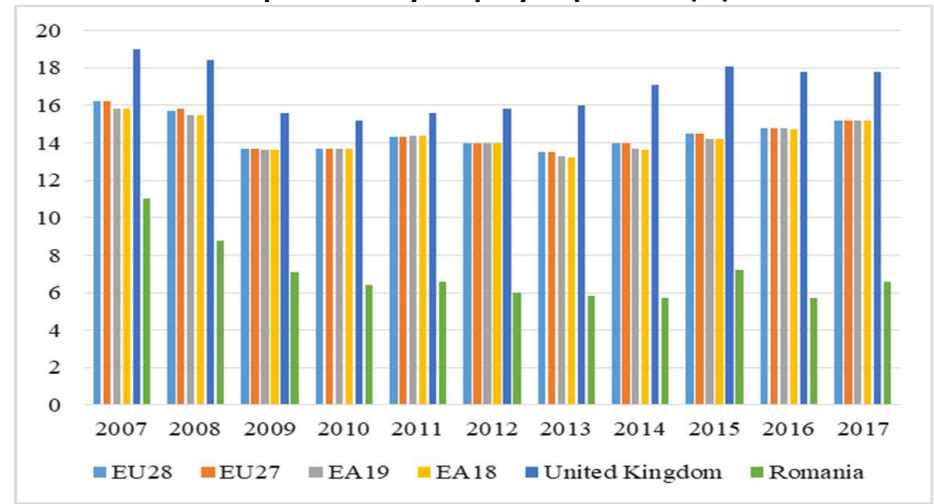

Source: Author's processing by EUROSTAT data

\subsection{Young NEETS}

Young NEETs refer to young people who are neither in employment nor in education and training between the ages of 18 and 24. In 2017, 14.3\% (EU28); 14.7\% (AE19), 13.2\% (MB), and $19.3 \%$ (RO) of the 18- to 24-year-olds were neither in the workplace nor in education or training, exposing to the risk of exclusion from the labor market and social security dependence. It can be seen from the chart that this category was strongly affected by the economic crisis in all analysed 


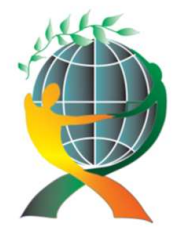

\author{
(online) $=$ ISSN $2285-3642$ \\ ISSN-L = $2285-3642$ \\ Journal of Economic Development, Environment and People \\ Volume 8, Issue 3, 2019 \\ URL: http://jedep.spiruharet.ro \\ e-mail: office jedep@spiruharet.ro
}

cases, and in Romania there were values well above those in the EU28 starting in 2010. In the case of the inactivity rate of the young NEETs, the higher values in the case of Romania, starting in 2010. The values registered in 2017 are: 12,4\% (EU28); 7.5\% (AE19); 8\% (MB) and 12.4\% (RO).

Graph 7: Inactivity rate of young NEETs, $\%$ of population aged $18-24$

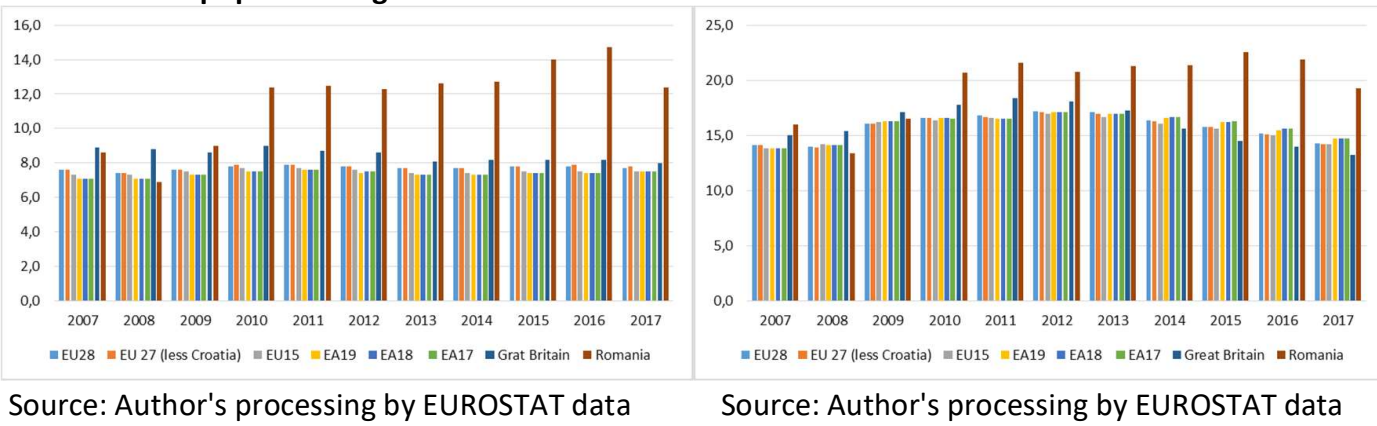

\title{
3.5. Graphic correlations
}

\section{$>$ the correlation between the employment rate and the vacancy rate}

The correlation curve between the employment rate and the vacancy rate in all three analysed cases (EU28, Great Britain and Romania) shows 3 phases specific to the contraction, trough point and the expansion. Both in the case of Great Britain and in the case of Romania, there is an obvious tendency to increase the employment rate with the increase of vacancies starting with 2013. In the case of Romania, after 2016, the curve moves to the right, but the values of the vacancy rate are significantly lower than those recorded for the EU28 and the Great Britain. The increase of about five percent of the employment rate in Romania was accompanied by the decrease by about one percent of the vacancy rate, while in the other analysed cases the vacancy rate slightly increased during the analysed period.

Graph 9: Romania, 2007-2018

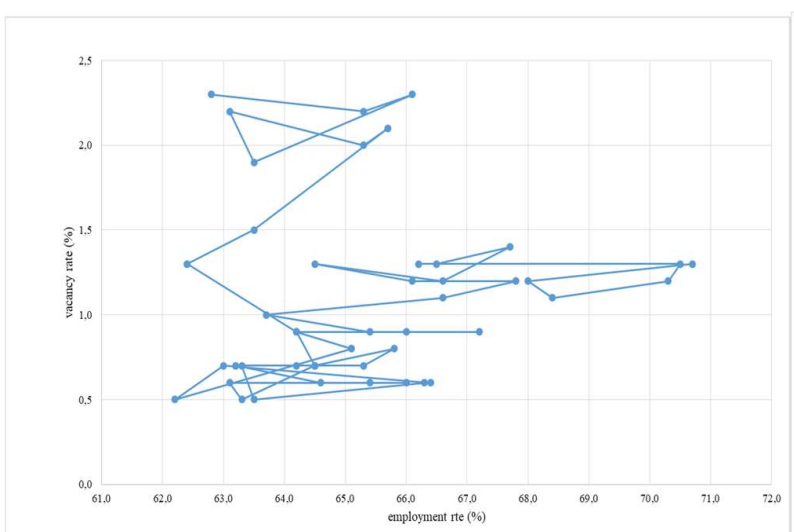

Source: Author's processing by EUROSTAT data
Graph 10: Great Britain, 2007-2018

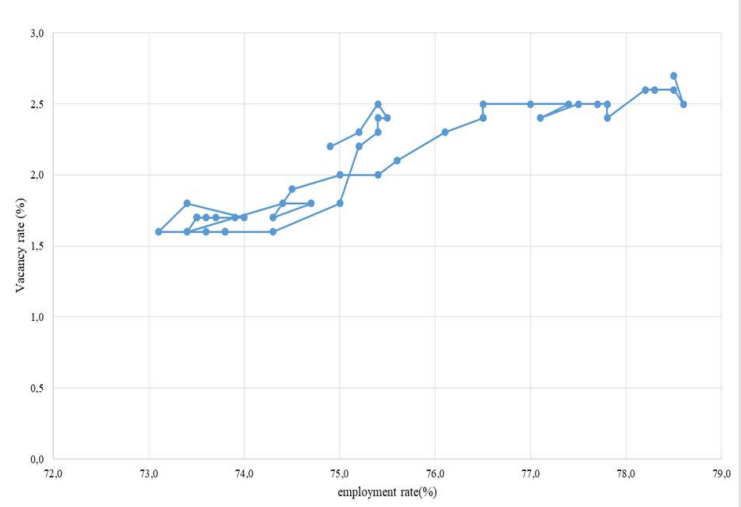

Source: Author's processing by EUROSTAT data 


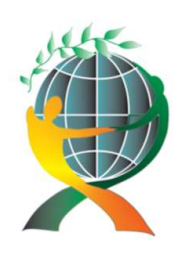

\author{
(online) = ISSN $2285-3642$ \\ ISSN-L = $2285-3642$ \\ Journal of Economic Development, Environment and People \\ Volume 8, Issue 3, 2019 \\ URL: http://jedep.spiruharet.ro \\ e-mail: office jedep@spiruharet.ro
}

\title{
the correlation between employment rate and productivity
}

It can be noticed that although the correlation between labor productivity and employment rate exists both at the level of the Romanian economy as well as of the Great Britain and the whole of the European economy, which is experiencing a sharp increase after the economic crisis and the global recession in 2008 2013, however, for Romania, this correlation is not so significant. This is a zigzag way in the case of Romania, unlike the linear and monotonous ascendant course after the crisis, of the British economy, for example. This path of the Romanian economy is the reflection of a defective economic structure, unstable and with a reduced capacity to generate jobs. In fact, what is noticeable is a rather low correlation between high productivity gains, it is true from extremely low levels and gains in terms of employment. In a decade, of course, marked by the episode of the crisis and the global recession, for 40 percentage points earned by labor productivity, the employment rate for the 20-64 age group earns just 5 percentage points.

Graph 11: Romania, 2007-2018

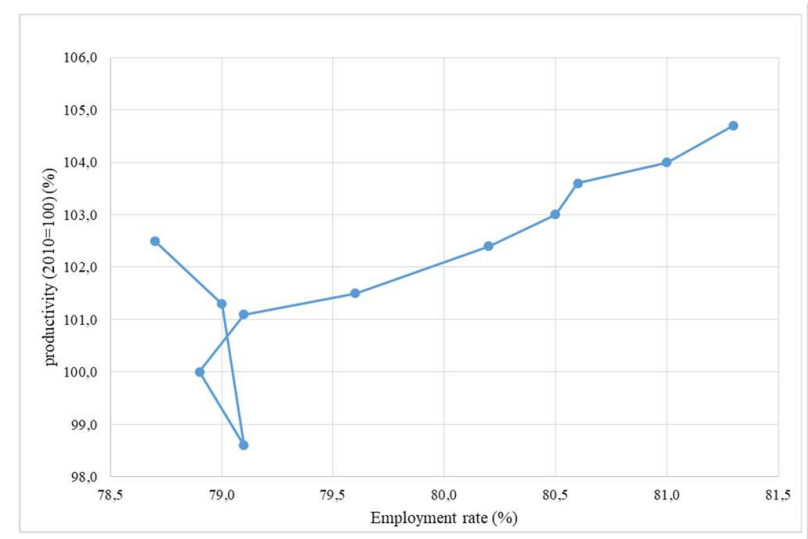

Source: Author's processing by EUROSTAT data
Graph 12: Great Britain, 2007-2018

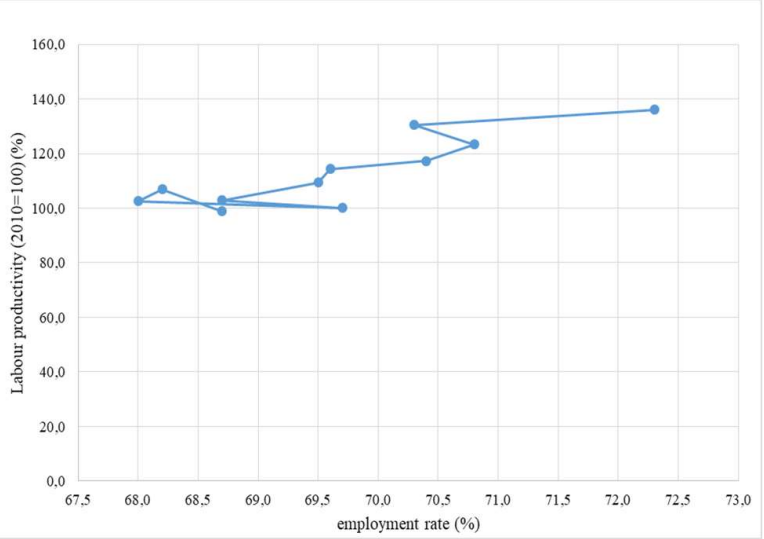

Source: Author's processing by EUROSTAT data

\section{Conclusions}

The relative size of the working-age population is falling at the EU-28 level due to the aging of the population, with economic migration becoming increasingly important in order to cope with a declining workforce and skills shortage. The EU28 faces a growing but aging population, driven by low fertility rates and a steady increase in life expectancy. Although there was an increase in the number of the employed population in the EU28, there are countries where there have been decreases, the highest in Romania. Considerably lower employment rates for young people aged 20-29 compared to active ages (20-64) reflect the less secure position of young people on the labor market, which makes their employment be more sensitive to macroeconomic fluctuations than adult employment. Professional training and the acquisition of skills required on the market play an important role in increasing employment in the labor market. The gender gap in employment is decreasing at EU28 level and rising in Romania as a result of the low employment rate of women, especially in rural areas. In 2017, following the growth of GDP and employment, the share of newly employed persons was at the highest level in 2009 in the EU28, namely 15.2\% (2017), compared with $13.7 \%$ (2009). In Romania, employment opportunities are significantly lower than in the rest 


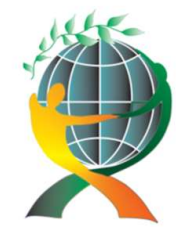

\author{
(online) = ISSN $2285-3642$ \\ ISSN-L = $2285-3642$ \\ Journal of Economic Development, Environment and People \\ Volume 8, Issue 3, 2019 \\ URL: http://jedep.spiruharet.ro \\ e-mail: office jedep@spiruharet.ro
}

of the analysed cases, and this explains the continued attractiveness of the mobility movement of Romanian workers to the economically advanced Member States.

\title{
5. Important Information
}

Parts of the article were presented at The National Economic Conference-CEN 2019, organized by Spiru Haret University.

\section{References}

[1] Cedefop. Future skill needs in Europe: critical labour force trends. Luxembourg: Publications Office. Cedefop research paper; No 59. http://dx.doi.org/ 10.2801/56396, 2016.

[2] W. Eichhorst,, T. Boeri, A. De Coen, V. Galasso, M. Kendzia and N. Steiber, , How to combine the entry of young people in the labour market with the retention of older workers? IZA Journal of European Labor Studies, 3(19), 2014.

[3] European Commission. Employment and Social Developments in Europe 2018, available at https://ec.europa.eu/social/main.jsp?catld=738\&langld=en\&publd=8110\&furtherPubs=yes, 2018.

[4] European Commission. Employment and Social Developments in Europe, Annual Review 2017, http://data.europa.eu/doi/10.2767/144714, 2017,

[5] European Commission Demography Report, Employment, Social Affaires \&Inclusion, 2015, Eurostat https://ec.europa.eu/eurostat/documents/7330775/7339482/Demography+report+\%E2\%80\%93+2015+edition/ce 8144e3-8e9b-427d-b6a2-61ff42950d41

[6] M. Ghenta. Characteristic of in-work poverty - a comparison between Romania and European Union, Journal of Economic Development, Environment and People, Volume 6, Issue 3, 2017, ISSN 2285 3642 - http://ojs.spiruharet.ro/index.php/jedep/article/view/63175

[7] D. Gros. Improvement in European labor force participation. IZA World of Labor 2019: 449 doi: 10.15185/izawol.449

[8] M. E. Kaminska, M. Kahancová. Emigration and labour shortages: An opportunity for trade unions in the New Member States?, 2011, Crossref DOI link: https://doi.org/10.1177/0959680111400916

[9] OECD. Summary note of OECD workshop, OECD workshop on Policies and Strategies for Demographic Change: Skills, Employment and Sustainable Development, 2011, OECD, Paris.

[10] OECD. Demographic Change and Local Development: Shrinkage, Regeneration and Social Dynamics, 2012, OECD, Paris.

[11] D. Pașnicu. Suporting SMEs in creating Jobs, Journal of Economic Development Environment and People (JEDEP), Editura Fundația România de Mâine, ISSN 2285-3642, 2018, ISSN-L = 2285 - 3642, vol 7, issue1, pg15-22, DOI: https://doi.org/10.26458/jedep.v7i1.575

[12] A. Trif, A.Koukiadaki, and M. Kahancová. The rise of the dual labour market: fighting precarious employment in the new member states through industrial relations (PRECARIR), 2016, Technical Report. European Commission. 